\title{
29. COSTA RICA RIFT BOREHOLE SEISMIC EXPERIMENT, DEEP SEA DRILLING PROJECT HOLE 504B, LEG $92^{1}$
}

\author{
S. A. Little and R. A. Stephen, Woods Hole Oceanographic Institution ${ }^{2}$
}

\begin{abstract}
An Oblique Seismic Experiment (OSE) was carried out down DSDP Hole 504B, located south of the Costa Rica Rift (crustal age: 5.9 m.y.).

A velocity-depth function with upper crustal velocities greater than $4 \mathrm{~km} / \mathrm{s}$ was determined using linear traveltime inversion, forward modelling, and amplitude analysis. Considerable lateral variability in shallow, upper crustal seismic velocity and thus rock porosity is suggested by the misfit between forward models of the sonic logging results obtained on Leg 83 and the data obtained from this OSE.

Traveltime analysis of this data set reveals the presence of horizontal anisotropy of magnitude $4-4.8 \mathrm{~km} / \mathrm{s}$, with the higher velocity in the east-west direction, parallel to the ridge axis, and the lower velocity north-south, perpendicular to the ridge axis. Large-scale fractures with preferred orientation probably cause the seismic anisotropy.
\end{abstract}

\section{INTRODUCTION}

The borehole seismic experiment conducted in DSDP Hole 504B south of the Costa Rica Rift sought information on the velocity-depth structure, seismic anisotropy, and heterogeneity of Layer 2 in young oceanic crust. The information obtained in this Oblique Seismic Experiment (OSE) is on a scale of hundreds of meters and, when compared with the extensive, smaller-scale downhole logging measurements made at Hole 504B, provides a rare synoptic view of physical rock properties and largescale seismic structure.

The Oblique Seismic Experiment entails placing a three-axis seismometer at various depths down a borehole, generating a series of explosions on the sea surface and recording arrival times and amplitudes for each shot (Fig. 1). The data can then be used to determine the detailed velocity-depth structure, the presence and orientation of seismic anisotropy, and lateral heterogeneity. The OSE results, coupled with the recovered rock section and various downhole measurements (e.g., porosity, sonic velocity, crack density, and resistivity), can help resolve such questions as: (1) How is large-scale seismic velocity related to in situ borehole mineralogy and crack structure? (2) If there is anisotropy, what is its type and significance? (3) Is it due to crack orientation and related to crustal formation processes?

The success of three previous Oblique Seismic Experiments (Fig. 2): south of the Bermuda Rise on Leg 52 (Stephen, 1978, 1979; Stephen et al. 1979, 1980), in the Tamayo Fracture Zone area on Leg 65 (Stephen et. al., 1983) and near the Costa Rica Rift in Hole 504B on Leg 70 (Stephen, 1983; Stephen and Harding, 1983), has proven the value of such experiments. In the Bermuda Rise experiment, good-quality three-component amplitude and traveltime data helped produce velocity-depth functions

\footnotetext{
${ }^{1}$ Anderson, R. N., Honnorez, J., Becker, K., et al., Init. Repts. DSDP, 83: Washington (U.S. Govt. Printing Office).

2 Address: Woods Hole Oceanographic Institution, Woods Hole, MA 02543.
}



Figure 1. A schematic diagram of a borehole seismic experiment. The drill ship maintains its position over the borehole and monitors the downhole geophone while a shooting ship sails concentric circles and radial lines. A generalized oceanic crustal structure and velocity-depth function are shown.

for both compressional (P) and shear (S) waves. Polarization analysis of the data revealed the shear-wave splitting indicative of seismic anisotropy (Stephen, 1981).

The Tamayo Fracture Zone OSE, near the Gulf of California, yielded only vertical component data, but synthetic seismogram analysis (Stephen, 1977; Stephen et al., 1983) helped produce a well-constrained velocitydepth function.

The previous Hole 504B OSE, on DSDP Leg 70, obtained only traveltime data because the seismometer failed when it encountered the high temperatures in the borehole $\left(120^{\circ} \mathrm{C}\right)$. The traveltime data alone from two ocean- 


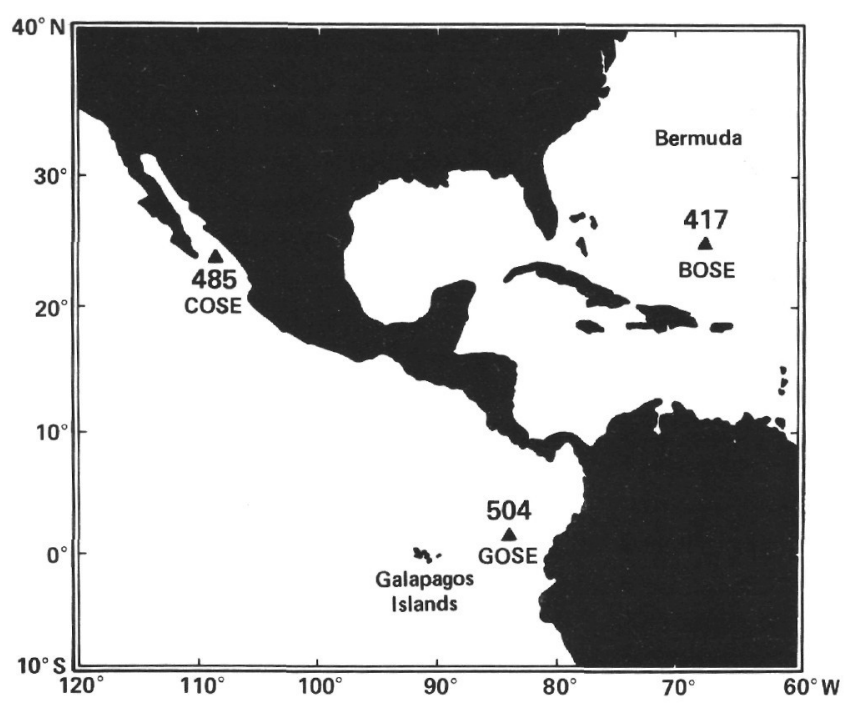

Figure 2. The locations of the three previous oblique seismic experiments. California Oblique Seismic Experiment (COSE) in the Gulf of California, Bermuda Oblique Seismic Experiment (BOSE) south of Bermuda, and Galapagos Oblique Seismic Experiment (GOSE) in Hole 504B near the Galapagos Islands.

bottom hydrophones and two borehole geophone positions made it possible to determine a P-wave velocitydepth function, but the lack of amplitude data precluded further constraining the velocity-depth function with forward, synthetic seismogram modelling.

This experiment, on Leg 92 (Fig. 3), obtained over 900 good-quality, three-component seismograms. As explained later, the Dorman and Jacobson (1981) inversion scheme, modified by Stephen and Harding (1983) for use with oblique seismic experiments, produced a velocity-depth structure to a depth of $1.4 \mathrm{~km}$ below the sediment/basement interface.

Houtz and Ewing (1976) defined seismic Layer 2A as the low-velocity igneous layer in upper oceanic lithosphere with P-wave velocity of about $3-4 \mathrm{~km} / \mathrm{s}$. This is the first layer encountered below the sediment/basement interface. They found, using conventional seismic refraction studies, that in the east Pacific the low-velocity seismic Layer $2 \mathrm{~A}$ thins with increasing age, from $700 \mathrm{~m}$ at the ridge (zero age) to $100 \mathrm{~m}$ in $30 \mathrm{~m} . \mathrm{y}$. old crust. For Site 504 on 5.9 m.y. old Pacific ocean crust, they would predict $740 \pm 230 \mathrm{~m}$ of Layer $2 \mathrm{~A}$. However, the lowest (and shallowest) velocity detected on this experiment was $4.3 \mathrm{~km} / \mathrm{s}$. The velocities found on the Leg 92 OSE agree with a previous sonobuoy seismic refraction experiment (Langseth et al., 1983) carried out near Site 504 and with the OSE conducted on Leg 70, both of which found unusually high, shallow velocities in this area.

The sonic logging experiment run on Leg 83 (Newmark et al., Salisbury et al., both this volume) did detect low velocities in the upper portion of the hole, starting at $2 \mathrm{~km} / \mathrm{s}$ and increasing to $4.3 \mathrm{~km} / \mathrm{s}$ at about $200 \mathrm{~m}$ into basement. The logging results will be compared to the Leg 92 OSE results later in this chapter.

Traveltime analysis of P-wave arrivals revealed seismic anisotropy in upper Layer 2 near Hole 504B, with a velocity of $4.8 \mathrm{~km} / \mathrm{s}$ in the east-west direction parallel

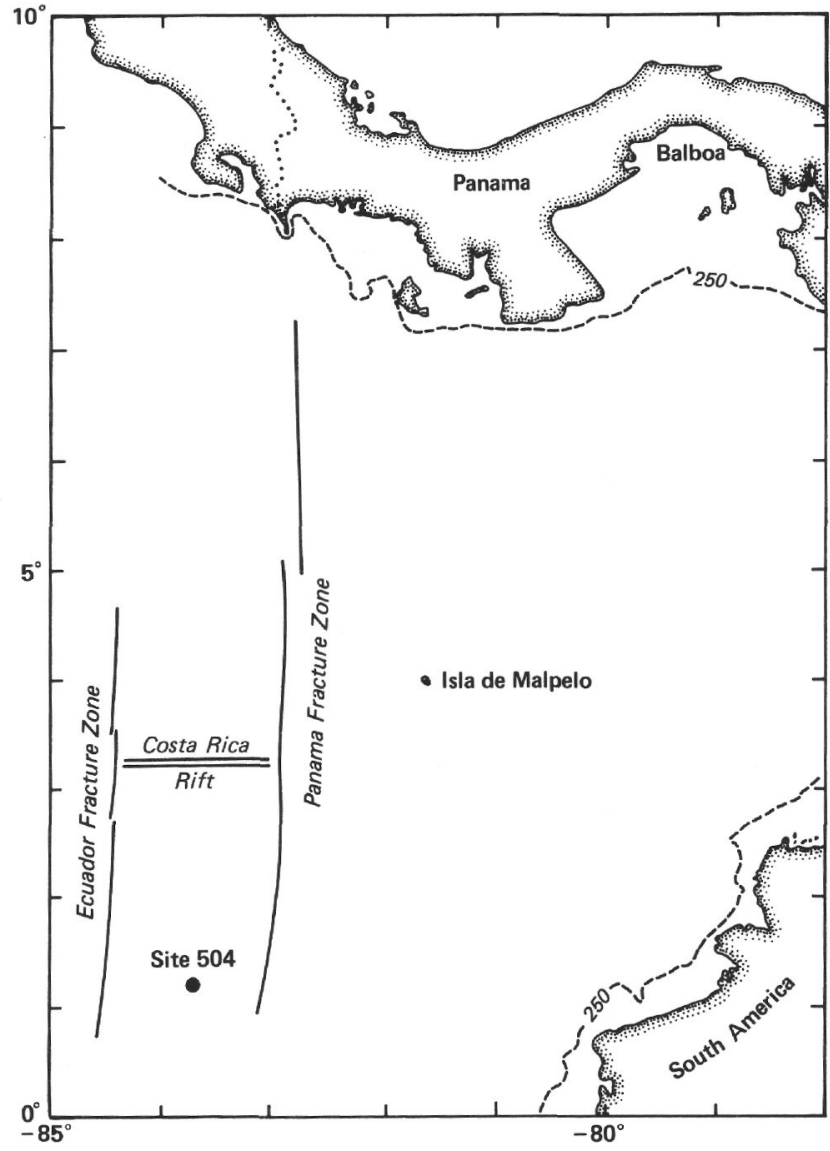

Figure 3. Location of this experiment, Leg 92, in Hole 504B, $200 \mathrm{~km}$ south of the Costa Rica Rift: $1^{\circ} 14 \mathrm{~N}, 83^{\circ} 44 \mathrm{~W}$.

to the Costa Rica Rift axis, and a velocity of $4 \mathrm{~km} / \mathrm{s}$ in the north-south direction. Preferred crack orientation on a scale of meters may cause this anisotropy (Stephen, 1981). The linear block faulting observed at the Mid-Atlantic Ridge (Ballard et al., 1975; Ballard and van Andel, 1977; Macdonald and Luyendyk, 1977; Luyendyk and Macdonald, 1977) produces cracks with a preferred orientation parallel to the spreading axis. Macdonald and Luyendyk substantiated this at one site by finding only a $6^{\circ}$ standard deviation in the orientation of 219 faults and fissures. If similar block faulting helped form the 504B area, with fissures and fractures paralleling the Costa Rica Rift spreading axis, then it appears that the compressional wave velocity is a maximum parallel to these cracks and a minimum perpendicular to them.

These traveltime anisotropy results will be checked in a later paper by examining the polarization of shear waves-another indicator of anisotropy.

\section{BACKGROUND}

Hole 504B is located $200 \mathrm{~km}$ south of the Costa Rica Rift on 5.9 m.y. old crust in an area with a high sedimentation rate. The $274.5 \mathrm{~m}$ of sediment at the drill site effectively seal the upper crust from penetration by ambient seawater (Anderson and Zoback, 1982; Zoback and Anderson, 1983; Langseth et al., 1983). Heat flow studies in the area indicate that near Hole 504B a region of 
conductive cooling prevails (Hobart et al., this volume), because the observed heat flow values match the theoretically predicted values for a conductively cooling crust (Lister, 1977; Parsons and Sclater, 1977).

Site 504 was drilled in conjunction with Site 505, located closer to the Rift on much younger, less sedimented, 3.9 m.y. old crust. Here, numerous basalt outcrops occur ( $17 \%$ of the seafloor) and heat-flow values fall below those theoretically predicted by simple conductive cooling. This means that Site 505 lacks an impenetrable sediment cap, and hydrothermal circulation freely mixes with ambient seawater (Langseth et al., 1983; Hobart et al., this volume) to advectively cool the upper oceanic crust. The initial purpose of drilling at these two sites was to study the differences between capped and uncapped upper oceanic lithosphere. Unfortunately, it is not possible to reenter Hole 505 to conduct an OSE for comparison with Hole 504B.

Hydrothermal circulation may also occur in the region of Hole 504B, but beneath the impermeable sediment layer. After the initial penetration of the sediment cap, temperature measurements on Leg 69 (December 1979) revealed a downhole flow of water at a rate of 90 $\mathrm{m} / \mathrm{hr}$. (Becker et al. 1983); by Leg 83 in November 1981 it had slowed to $25 \mathrm{~m} / \mathrm{hr}$. and by April 1983 to 2-3 m/ hr. (Becker et al., this volume). Anderson and Zoback (1982) interpreted this downflow of water to be an indication of underpressure caused by the downgoing limb of a convection cell. A high-porosity zone covering a depth from 0-100 m below the sediment/basement interface was determined from temperature, packer (pressure), and porosity measurements (Becker et al., 1982; Anderson and Zoback, 1982; Becker, this volume). This zone within the hole is also marked by depressed water temperatures, which indicate that all or nearly all of the downflow of water is exiting through the wall between 0 and $100 \mathrm{~m}$. The zone extends out to a radial distance of at least $1 \mathrm{~km}$, judging by water-volume flow estimates (Becker et al., 1983).

The distribution of the size, shape, and orientation of the cracks causing the porosity affects (or may even control) the circulation of water in upper oceanic crust. Since the size, shape, and orientation of cracks also significantly affects seismic velocity, seismic analysis can help determine the porosity distribution and hence hydrothermal circulation routes. Further, correlations between the large-scale crack and porosity structure seen with seismic methods and smaller-scale logging experiments may help generalize the results of borehole tests like porosity, resistivity, and televiewer (cracks) to scales of kilometers instead of meters.

\section{EXPERIMENTAL PROCEDURE}

On Leg 92, the Glomar Challenger reentered Hole 504B, lowered the three-component borehole geophone into basement, and clamped the receiver at four locations spaced approximately $200 \mathrm{~m}$ apart: 3780 , $4010,4190,4405 \mathrm{~m}$ below sea level (BSL), or equivalently 42, 272, 452, and $667 \mathrm{~m}$ into basement. The high temperatures (up to $160^{\circ} \mathrm{C}$ ) in Hole 504B, which caused the failure of the borehole seismometer on Leg 70, necessitated the use of a new seismometer designed and tested for temperatures up to $200^{\circ} \mathrm{C}$. The pressure case, clamping mechanism, and geophones were purchased from GeoSpace Corporation. Woods Hole Oceanographic Institution (WHOI) added a three-com- ponent variable-gain preamplifier, and the complete system worked well throughout the experiment. While the Challenger maintained position over the hole, the shooting ship, the Ellen B. Scripps, steered a series of radial lines and concentric circles centered on the hole, firing $7 \mathrm{~kg}$ shots (bubble pulse $0.10-0.15 \mathrm{~s}$ ) every $500 \mathrm{~m}$ out to a distance of $8 \mathrm{~km}$. This sequence was repeated at each geophone position, with varying degrees of success. The repeated failure of a high-temperature adapter which connects the Gearhart-Owens logging cable to the Schlumberger tool head on the borehole seismometer prevented the successful collection of all 1600 planned shot records. Despite the repeated flooding of this connector, the Challenger recorded three-component true-amplitude data on magnetic tape and ultraviolet (UV) paper while the shooting ship completed a program of 994 shots.

The shot locations for each of the four geophone positions are shown in Figure 4. With the geophone clamped at $3780 \mathrm{~m} \mathrm{BSL}\left(20^{\circ} \mathrm{C}\right.$, 349 shots $)$ and $4010 \mathrm{~m} \mathrm{BSL}\left(100^{\circ} \mathrm{C}, 359\right.$ shots) complete shooting programs were obtained with four concentric circles $(2,4,6,8 \mathrm{~km}$ radius) and eight radial lines to $8 \mathrm{~km}$ (N-S, E-W, NE-SW, NW-SE). At 4190 m BSL $\left(120^{\circ} \mathrm{C}, 71\right.$ shots $)$, a $6 \mathrm{~km}$ radius circle was completed, and at $4405 \mathrm{~m}$ BSL $\left(140^{\circ} \mathrm{C}, 132\right.$ shots) a $6 \mathrm{~km}$ radius circle, $\mathrm{N}, \mathrm{S}, \mathrm{E}$, and $\mathrm{W}$ radial lines, and a SW quadrant line were shot. Because the connector flooded, the geophone was not clamped in the dike sequence which starts at about $4520 \mathrm{~m}$ BSL.

The depth under each shot was recorded on a Precision Depth Recorder. The shot range was measured with a Del Norte radar system mounted on both ships to an accuracy of $10 \mathrm{~m}$. The greatest source of error in the traveltimes is the flight-time corrections used to account for the fact that the explosions occur at some distance behind and below the ship. A towed hydrophone behind the shooting ship records the shot instant and then corrections are applied using the ship's speed and the sink rate of the shot to determine the actual time of the shot instant. These corrections are on the scale of $0.106 \pm 0.005$ s (Stephen et al., 1979).

The dominant seismic wavelength is determined by multiplying the bubble-pulse period by the seismic velocity of the crust. The seismic wavelength limits the resolution of the velocity-depth function. In this experiment the wavelength is about $400 \mathrm{~m}$. Synthetic seismogram analysis (White and Stephen, 1980) indicates for upper oceanic crustal models that changes in gradient thickness of one quarter of a wavelength or less cause considerable changes in compressional and shear wave amplitudes. We are confident that, under the assumption of lateral homogeneity, the resolution of our experiment is about $100 \mathrm{~m}$.

\section{DATA REDUCTION}

This section discusses two methods for determining the velocity-depth structure: (1) inflection point analysis for finding the velocity at each receiver (Stephen and Harding, 1983), and (2) a linear inversion method for obtaining the velocity-depth function using data from all receiver depths simultaneously (Dorman and Jacobson, 1981; Stephen and Harding, 1983). These procedures need data nearly equally spaced (in range) so that they use only the radial lines for determining the velocity-depth function.

\section{Inflection Point Analysis}

The traveltime/distance curve can help independently determine the seismic velocity at the receiver. A sample record section with the P-, S-, and direct water-wave arrivals is shown in Figure 5, along with the ray paths for these waves from a $6 \mathrm{~km}$ shot. All of the following statements apply to $\mathrm{S}$ waves as well as $\mathrm{P}$ waves but only an analysis of $\mathrm{P}$ waves has been done in this paper. In an OSE, each shot has a P-wave traveltime $(T)$, a distance $(X)$, and a ray path characterized by a single ray parameter $(P$, units of time/distance). The ray parameter is constant for each ray and is defined by:

$$
P=\sin (i) / V_{\mathrm{i}} \text { (Snell's law), }
$$



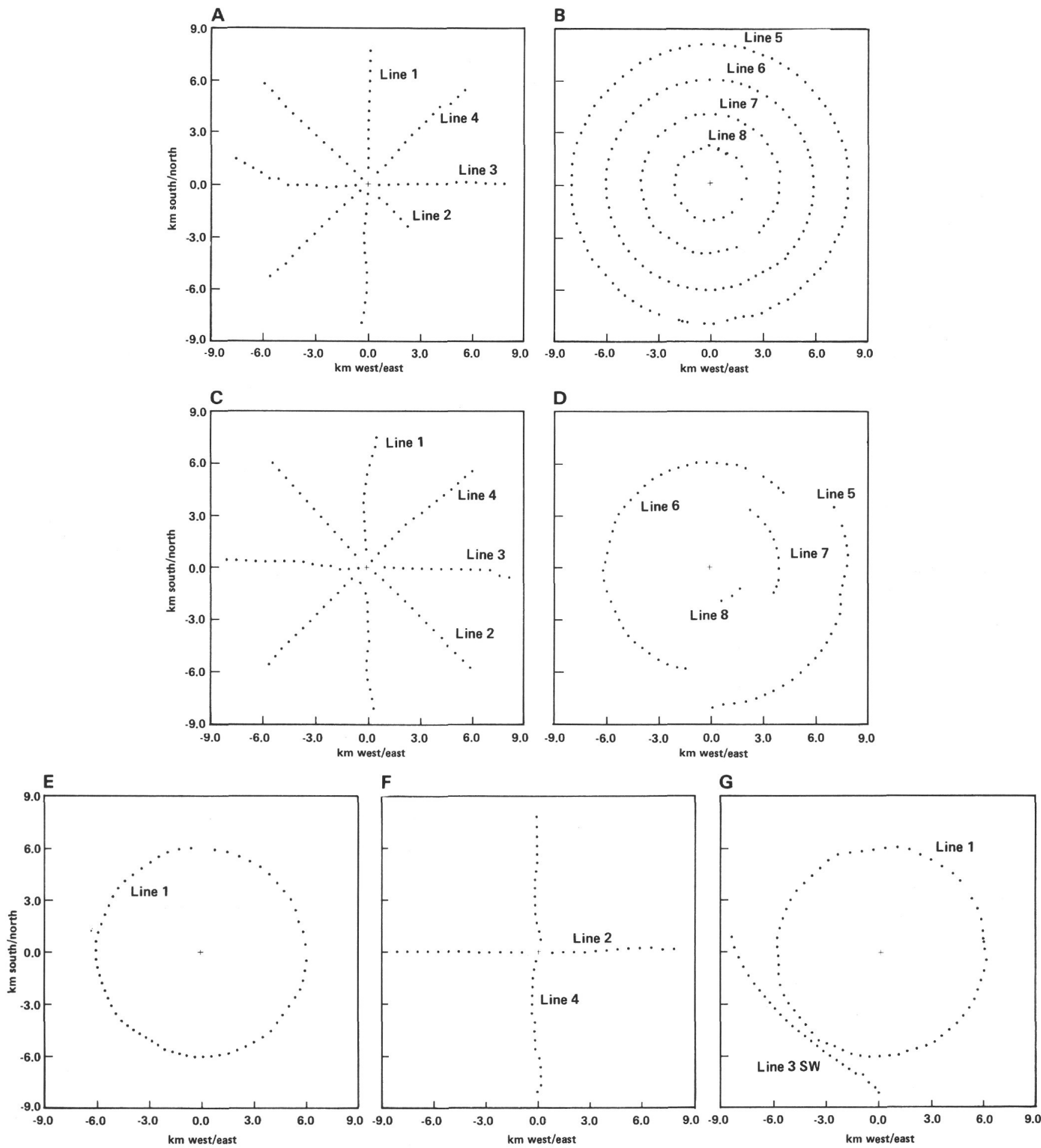

Figure 4. The shot positions recorded with the geophone clamped at varying distances into basement. A, B. $42 \mathrm{~m}$ (3780 m BSL): (A) Eight radial lines, E-W, N-S, NE-SW, SE-NW, shot out to a distance of $8 \mathrm{~km}$, and (B) four concentric circles of radii 2, 4, 6, and $8 \mathrm{~km} . \mathrm{C}, \mathrm{D} .272 \mathrm{~m}(4010 \mathrm{~m}$ BSL): (C) Four radial lines, E-W, N-S, NE-SW, SE-NW, shot out to a distance of $8 \mathrm{~km}$, and (D) four concentric circles of radii $2,4,6$, and $8 \mathrm{~km}$. The gaps in the circles are shots which were recorded on UV paper but not on magnetic tape. E. $452 \mathrm{~m}$ (4190 m BSL): One $6 \mathrm{~km}$-radius circle. F, G. $667 \mathrm{~m}$ (4405 m BSL): (F) two radial lines, N-S and E-W, out to a distance of $8 \mathrm{~km},(\mathrm{G}) 6 \mathrm{~km}$ circle and a SW quadrant line. 

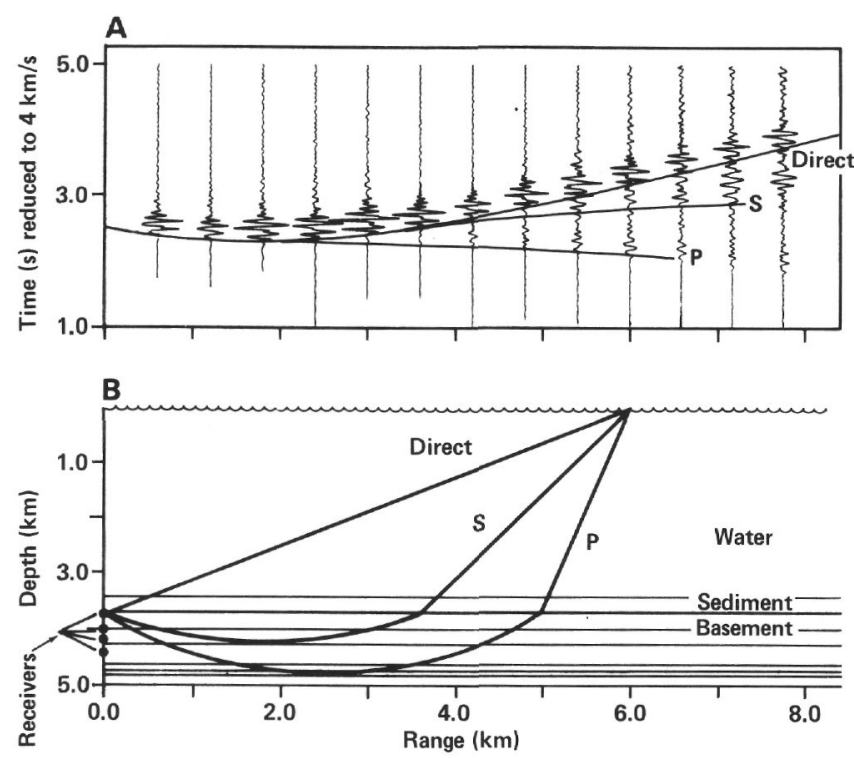

Figure 5. A. The three major arrivals on a record section for a shallow receiver ( $42 \mathrm{~m}$ into basement, line $4 \mathrm{SW}$, vertical), the first, a $\mathrm{P}$ wave, the second, an S wave, and lastly the direct water wave. B. Ray paths for a shot fired at $6 \mathrm{~km}$ (shallow receiver, $42 \mathrm{~m}$ into basement) give some indication of the layers sampled by each type of ray.

where $i$ is the angle of incidence of the ray onto layer $i$ (measured from the vertical) and $V_{\mathrm{i}}$ is the $\mathrm{P}$-wave velocity in that layer.

In a medium where velocity increases with depth, a ray will turn upward in the layer in which velocity equals the inverse of the ray parameter; this will be the deepest point reached by this ray. In this turning layer, $t$,

$$
i=i_{\mathrm{t}}=90^{\circ}, \sin \left(i_{\mathrm{t}}\right)=1 \text {, and so } P=1 / V_{\mathrm{t}} .
$$

Thus, the ray parameter equals the inverse of the velocity in the layer in which the ray turns, $V_{\mathrm{t}}$. In addition to this, the ray parameter of a source-to-receiver ray equals the slope of that point on a $T-X$ curve. This property helps determine the wave velocity in the layer containing the OSE borehole receiver.

This method cannot be used on conventional seismic records where the receiver is on the seafloor because both the traveltime inflection points and the low-amplitude direct water-wave arrivals found on OSE time-distance $(T-X)$ curves are not found on those of normal, seafloor receiver refraction experiments (for more on OSE water-wave arrivals see Stephen and Bolmer, in press). These differences arise because the OSE receiver is buried in the basement rather than resting on the seafloor. For receivers on the seafloor, the $T-X$ inflection point occurs at zero range (no horizontal distance between source and receiver), because there is no rock above the receiver. Compounding this if sediment is present, the water-wave arrival masks the P-wave arrivals at close range and the inflection point becomes impossible to discern. In contrast, the OSE $T-X$ inflection point occurs at a finite range (2-3 km for this experiment) and the waterwave arrival does not mask the $\mathrm{P}$-wave arrivals. Thus, as in Figure 6, the inflection point is quite evident and it corresponds to the ray which turns in the layer containing the receiver (i.e., the geophone depth). All previous rays impinge on the receiver from the rock above and all subsequent rays come up from below. The reciprocal of the slope at this inflection point equals the velocity at the receiver. Thus, we have a direct measurement of the $P$-wave velocity at each geophone to give an independent check on the results of the velocity-depth inversion. In Figure 6, the slope at the inflection point, $U_{\text {receiver }}$, equals the reciprocal of the velocity of ray $C$ when it turns at the receiver. Determining the slope at this inflection point for each OSE geophone position thus yields the P-wave velocity of the layer containing each receiver.

This procedure is used on each of the three receiver depths to produce three points in velocity-depth space.

\section{Velocity-Depth Inversion}

The five steps which reduce the $T-X$ data to a velocity-depth function are: (1) fit the data with a smooth curve, (2) reduce the data to the seafloor, (3) fit the data again, (4) optimally parameterize the data, and (5) invert for the velocity-depth function. These steps are outlined below.

1. The data from each of the three receiver depths are fit separately with a smooth curve to obtain the ray parameters (slopes) of each shot in order to reduce the data to the seafloor. The ray parameters for each shot are needed to determine the angle incidence of the ray



Figure 6. A typical OSE traveltime curve showing the inflection point $U_{\text {receiver }}$ corresponding to the ray $\mathrm{C}$. Before the inflection point all rays impinge upon the receiver from above and after the inflection point all rays impinge from below. This property can be used to determine the seismic velocity at the receiver, which is just equal to the reciprocal of the inflection-point slope. 
with the seafloor and, therefore, the distance traveled by the ray through water and sediment. Once this distance is known, the effect of the water and sediment column can be removed from the total traveltime of that ray.

A quadratic spline procedure does the curve-fitting. This step in the inversion process does not follow the curve-fitting method described in Stephen and Harding (1983). For the procedure used here, a quadratic spline (Shure and Chave, in press) fits a smooth curve to unreduced, P-wave, traveltime data. The spline procedure fits second-degree polynomials to the $T-X$ curve. Initially, the procedure calls for the input of an inflection point, which automatically becomes a knot (node) for polynomial fitting. Secondly, the procedure requests the number of knots; these are used to divide the $T$ - $X$ curve into approximately equally spaced sections on either side of the inflection point knot. Finally, parabolas are fitted in between these knots, minimizing the least-squares error. To keep with the assumed earth model of ever-increasing velocity with depth, the polynomials are constrained to have increasing slope on the left (short-range) side of the inflection point and decreasing slope on the right side (long-range). In addition, the slope at the origin must be zero since a ray incident from directly above the receiver (zero range) where $i=0$ has a ray parameter of $\sin (i)=$ 0 and consequently a slope of zero. For each of three geophone positions, only the P-wave first arrivals of the radial lines are used. For geophone at $4190 \mathrm{~m}$ BSL only a circle $(6 \mathrm{~km})$ was obtained, so data from that depth were not used in this inversion scheme.

2. The slopes obtained in step 1 are used to reduce the data from the sea surface to the sediment/basement interface and corrections for topography are made. The smooth bottom bathymetry, with variations rarely greater than $50 \mathrm{~m}$, is assumed to follow basement topography (Fig. 7). Therefore, when reducing traveltimes to the sediment/basement interface, we correct for depth using the Precision Depth Recorder output and assuming a constant sediment thickness $(275 \mathrm{~m}, \mathrm{P}$-wave velocity 1.6



$83^{\circ} 43.8^{\prime} W$

Figure 7. The bathymetry near Site 504 in $50 \mathrm{~m}$ contours shows smooth relief, enabling simplified reduction of the shots to the seafloor. The inner box (dashed line) is $18 \mathrm{~km}$ to a side. 
$\mathrm{km} / \mathrm{s}$ ). The constancy of sediment thickness in the two reflection profiles across Site 504 supports this simplifying assumption (Fig. 8).

3 . We refit the reduced data (for each of the three receiver positions) with a smooth curve to obtain the leastsquares error estimate and the curvature, which are needed for the subsequent parameterization. Again a quadratic spline is used in the curve-fitting. Since the number of knots and the location of the inflection point can vary the unreduced data are fitted, and the number of knots can vary when the reduced data are fitted, some criteria are needed to pick the optimum quadratic spline solutions. Often this is done by eye: the best-looking fit is picked from a series of plots. Dorman and Jacobson (1981) fitted the data with a fourth-order polynomial, then iterated through reducing it to the seafloor, fitting the reduced data, and using those new slopes to re-reduce the original data.

In this case, the procedure chooses knots and inflection-point locations to minimize both the least-squares error in the spline fit and the difference between the slope of the inflection point before and after reduction to the seafloor. Reducing the data from the sea surface to the seafloor should not change the value of the slope at the inflection point, since this value corresponds to the Pwave velocity at the receiver.

For the Leg 92 OSE this spline-fitting procedure resulted in knot number, inflection-point values, and velocities for the three geophone positions as given in Table 1 .


Figure 8. A. The interpretation of a N-S reflection profile across Hole 504B. The sediment follows basement. In addition the zone within $1 \mathrm{~km}$ of the hole has a constant slope downward to the south. B. The interpretation of an E-W reflection profile across Hole 504B. The sediment follows basement fairly closely. In addition, the zone within $1 \mathrm{~km}$ of the hole is approximately horizontal.
Table 1. Quadratic spline fitting results.

\begin{tabular}{|c|c|c|c|c|c|c|}
\hline \multirow{2}{*}{$\begin{array}{l}\text { Depth } \\
\text { into } \\
\text { basement } \\
\text { (m) }\end{array}$} & \multicolumn{3}{|c|}{ Unreduced to seafloor } & \multicolumn{3}{|c|}{ Reduced to seafloor } \\
\hline & Knots & $\begin{array}{l}\text { Inflection } \\
\text { point } \\
\text { (m) }\end{array}$ & $\begin{array}{l}\text { Velocity } \\
(\mathrm{km} / \mathrm{s})\end{array}$ & Knots & $\begin{array}{l}\text { Inflection } \\
\text { point } \\
(\mathrm{km})\end{array}$ & $\begin{array}{l}\text { Velocity } \\
(\mathrm{km} / \mathrm{s})\end{array}$ \\
\hline 42 & 9 & 2.45 & 4.3 & 5 & 0.00 & 4.3 \\
\hline 272 & 9 & 2.70 & 4.8 & 15 & 1.57 & 4.8 \\
\hline 667 & 9 & 2.85 & 5.1 & 13 & 1.70 & 5.0 \\
\hline
\end{tabular}

The spline-fitting procedures uses these values to find the slope and curvature of each point on the fitted curve and the least-squares error for the entire curve (for each of the three geophone positions).

4. The next step, described in Dorman and Jacobson (1979), uses the least-squares error estimates, slope, and curvature to fit optimum straight lines to the $T-X$ data. These straight lines are used to obtain meaningful ray parameter estimates. The data are then parameterized by tau and zeta, which are defined by:

$$
\begin{aligned}
& \tau=T-P X, \\
& \zeta=T+P X,
\end{aligned}
$$

where $T$ and $X$ refer to the midpoint of the straight-line segment and $\boldsymbol{P}$ is the slope of the tangent at that point.

In this data set, the optimization procedure finds between one and five straight lines per $T$ - $X$ curve, depending on the geophone position. The parameterized lines from all three geophone data sets and their error bounds are then passed on to the inversion procedure.

5. The Herglotz-Wiechert formulas [relating $Z(V)$ to $X(P)$ and $T(P)]$ provide the physical equations for the inversion. The change of variable yields a formula for the velocity gradient as a function of depth. It is this velocity gradient that the inversion procedure seeks to locate in $Z$, and a subsequent integration produces the velocity-depth function. The inversion takes all the parameterized lines from the optimization procedure, and assigns depths and error bounds to the constant-gradient layers between prescribed velocities. After integration, these become a mean velocity-depth function with 95\% confidence limits (see Fig. 9). The uppermost velocity has been chosen to be the velocity of the receiver at $42 \mathrm{~m}$ into basement $(4.3 \mathrm{~km} / \mathrm{s})$ since the inversion procedure does not give a velocity for $Z=0$.

To check the velocity-depth function we forward-model it using ray calculations (Fig. 10). In this figure, the solid lines represent the forward velocity-depth model with its $95 \%$ confidence limits for each of the three geophone positions involved in the inversion scheme. The upper line in each corresponds to the deeper bound on the velocity-depth curve and the lowest line in each corresponds to the shallower bound. The points represent the real Pwave first arrivals. The numerical values of the velocitydepth function are given in Table 2 . We further check the velocity-depth function by fitting the real amplitude records with the synthetic seismograms generated using the reflectivity method (Fuchs and Müller, 1971). Figure 


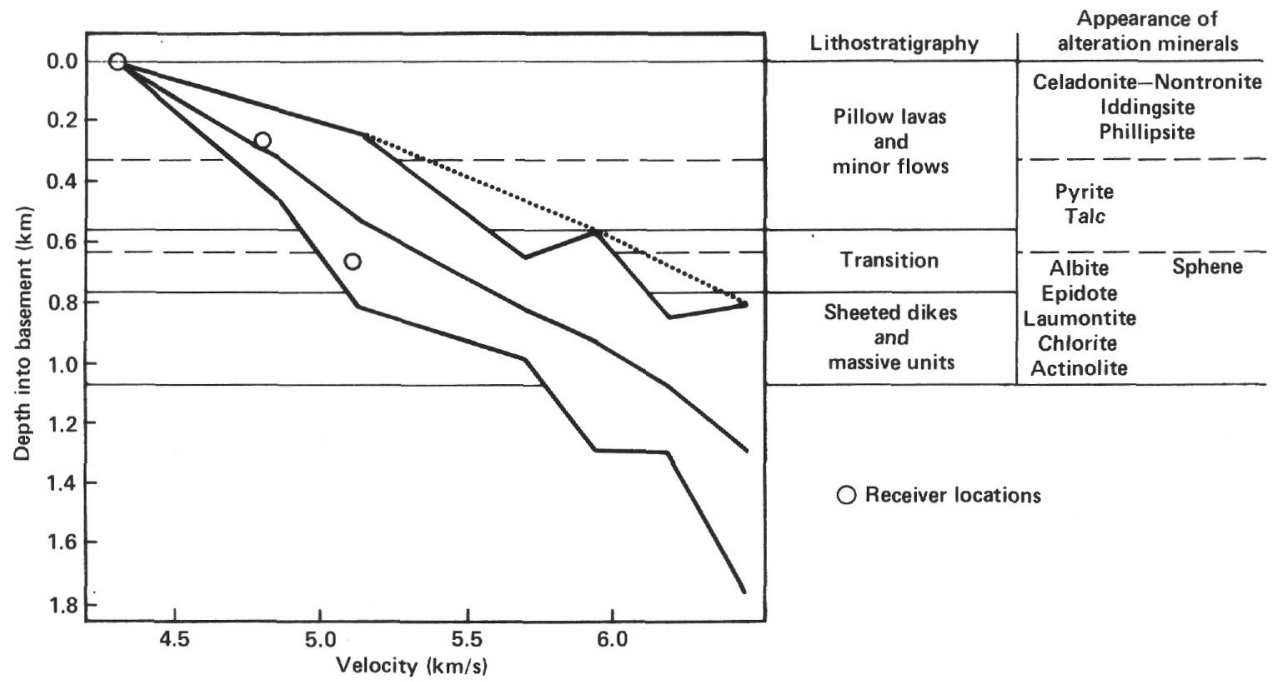

Figure 9. The velocity-depth function obtained in this experiment compared to the lithostratigraphy and appearance of alteration minerals. There is no strong correlation between the velocity-depth function and the geologic transitions in the hole. Also note that the lowest velocity appearing is $4.3 \mathrm{~km} / \mathrm{s}$, significantly higher than normal Layer $2 \mathrm{~A}$ velocities. The open circles denote the independently determined receiver velocities. The bounds are the $95 \%$ confidence limits to the mean velocity-depth function in the middle. The dotted line depicts the velocity-depth function used for the forward modelling of the bounds.

11 , shows the comparison of real P- and S-wave amplitudes with synthetic seismograms generated from the mean velocity-depth function, shown in Figure 9, for the three receivers: $42 \mathrm{~m}, 272 \mathrm{~m}$, and $667 \mathrm{~m}$ into basement. Shotsize variations can cause up to $12 \mathrm{~dB}$ of variation in amplitude between individual traces. Good fits are obtained in the general trends.

\section{Anisotropy Analysis}

The traveltimes of concentric circles were used to help detect azimuthal anisotropy. They have been range-corrected for the deviations of the shooting ship's paths from true circles. They have not been corrected for topography.

\section{DISCUSSION}

\section{Heterogeneity}

The record sections show considerable variation in amplitude for a given range depending on the bearing of the shot. This suggests some lateral inhomogeneity which can be verified with further synthetic modelling using the finite-difference method (Stephen, 1983).

\section{Velocity-Depth Function}

Figure 9 illustrates the lithostratigraphy of the hole compared to the velocity-depth structure from this OSE. There are no sharp transitions in velocity which could correspond to the transitions in either the rock type (pillow basalts to dikes) or the mineralogy. The large-scale velocity-depth structure cannot predict local geology, which has large variability within $8 \mathrm{~km}$ of the hole.

The velocity-depth structure has a low velocity of $4.3 \mathrm{~km} / \mathrm{s}$. This leads us to conclude, supported by the sonobuoy experiment and by the previous Leg 70 OSE, that there is a shallow, unusually high velocity layer in the vicinity of Hole 504B. Perhaps the thickness of Lay- er $2 \mathrm{~A}$ is more correlated to sediment thickness than to crustal age. Sediment thickness affects temperature and water circulation; thus, the thinning of Layer $2 \mathrm{~A}$ may be related to elevated temperature and a change in water circulation patterns (Stephen and Harding, 1983; CRRUST, 1982).

Logging experiments from Leg 83 (Salisbury et al., this volume) detected a shallow, low-velocity layer and a negative velocity gradient somewhat deeper (Fig. 12). The velocity-depth function from these logging results has been forward-modelled here, using synthetic seismograms, to determine whether the amplitudes of the P- and $\mathrm{S}$-wave arrivals match the OSE results. The synthetic seismograms for a receiver at $32 \mathrm{~m}$ into basement are compared in Figure 13. The upper portion shows the seismograms obtained when using the logging results. Note especially the low amplitudes on the $\mathrm{S}$ waves. The lower portion displays the synthetic seismograms resulting from the OSE velocity-depth function (which were also plotted in Fig. 11). These seismograms have significantly higher S-wave amplitudes, by an order of magnitude, than those from logging results. The velocitydepth function obtained on the logging experiment does not produce seismograms which match the data recovered on the OSE. The logging results give a detailed, localized velocity-depth function which cannot be generalized to scales of kilometers. In contrast, the OSE produces a large-scale velocity-depth function which does not give detailed information about the environment immediately around the borehole (scale of meters).

\section{Anisotropy}

The only circle with significant azimuthal variation in traveltimes is the $2 \mathrm{~km}$ circle shot to the receiver located $42 \mathrm{~m}$ into basement (see Fig. 14). There is an obvious two period variation indicative of anisotropy. This 

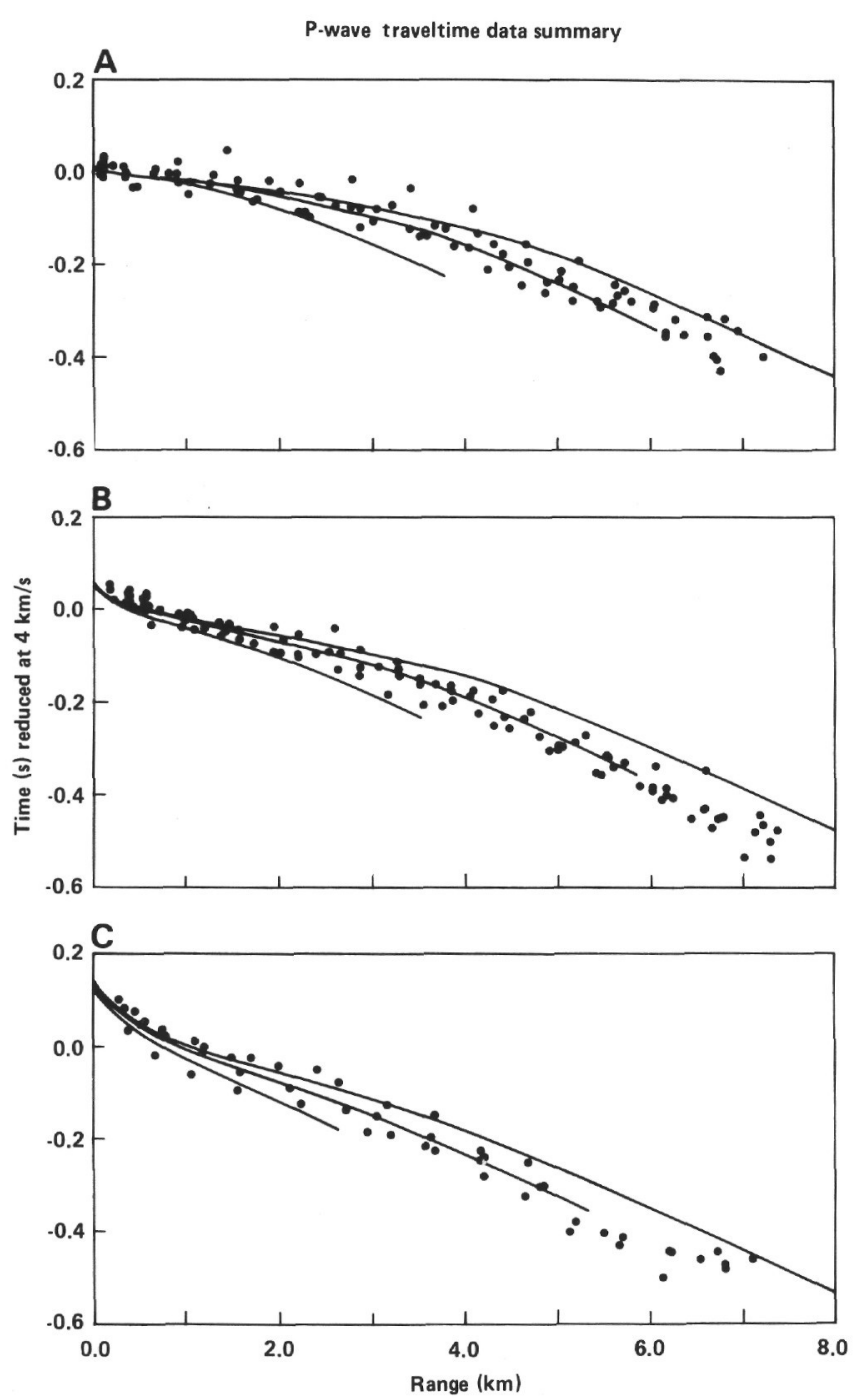

Figure 10. Comparison of the forward model of the velocity-depth function and its bounds, using ray theory, with the actual data. A. Receiver $42 \mathrm{~m}$ into basement. B. Receiver $272 \mathrm{~m}$ into basement. C. Receiver $667 \mathrm{~m}$ into basement. The traveltimes have been reduced at $4 \mathrm{~km} / \mathrm{s}$ so that any horizontal line corresponds to a velocity of 4 $\mathrm{km} / \mathrm{s}$.

Table 2. Numerical values of velocity-depth function, Leg 92 OSE.

\begin{tabular}{cc}
\hline $\begin{array}{c}\text { P-wave } \\
\text { velocity } \\
\text { (km/s) }\end{array}$ & $\begin{array}{c}\text { Depth } \\
\text { (km into basement) }\end{array}$ \\
\hline 4.30 & 0.000 \\
4.83 & 0.264 \\
5.11 & 0.476 \\
5.67 & 0.766 \\
5.92 & 0.876 \\
6.16 & 1.017 \\
6.43 & 1.231 \\
\hline
\end{tabular}

is confirmed by Fourier decomposition of the data (Table 3). Two reflection profiles from this area (Langseth et al., unpublished data), one east-west and the other north-south (Fig. 8), show a sloping basement in the zone sampled by the $2 \mathrm{~km}$ shots (see Fig. 15 for the ray paths of the $2 \mathrm{~km}$ circle). This topographic variation would cause a one-period traveltime dependence and is not responsible for the observed two-period dependence. The dominant, two-period variation corresponds to a high east-west velocity of $4.8 \mathrm{~km} / \mathrm{s}$ and a low north-south velocity of $4 \mathrm{~km} / \mathrm{s}$. The traveltime analysis based on the radial data from all azimuths gave an average velocity of $4.3 \mathrm{~km} / \mathrm{s}$ and is consistent with the anisotropy results. Note that the $2 \mathrm{~km}$ circle samples only approximately the upper $50-100 \mathrm{~m}$ and at a range of less than one kilometer from the hole $(0.75 \mathrm{~km}$ of rock, nominally 4.3 $\mathrm{km} / \mathrm{s}$ ). Therefore, the anisotropy must be localized, perhaps because the cracks are oriented to the axis of crustal spreading. Possible reasons for the absence of this anisotropy in the larger circles are:

1. The lower signal-to-noise ratio in the longer-range shots makes picking the first arrivals more difficult and increases the scatter in the traveltimes. This reduced signal may result from the facts that longer ranges have turning rays with more emergent wave forms, and longer ray depths increase the chance of attenuation and scattering and subsequent loss of wave energy.

2. The anisotropy could be confined to the upper hundred or so meters of crust, where this anisotropy would have less effect on the traveltime of the deeper rays from larger ranges.

3. The anisotropy could be localized to $1-2 \mathrm{~km}$ lateral blocks, where the longer ray paths of the larger circles average out this small-scale anisotropy.

\section{CONCLUSIONS}

The Leg 92 Oblique Seismic Experiment succeeded in collecting an impressive amount of data, including records from a seismometer $667 \mathrm{~m}$ into basement, the deepest in oceanic crust.

The velocity-depth function obtained from these data shows an unusually high velocity in the upper crust, compared to other crust of this age. This could be due to the unusually high amount of sediment in this area sealing the crust from ambient seawater, raising the temperature of the crust, and accelerating crack infilling and cementation. This change in circulation causes the upper crust to have velocities similar to those of much older crust.

Changes in the slope of the velocity-depth function do not match changes in lithostratigraphy or mineralogy of Hole 504B. Therefore, the velocity-depth function obtained with this OSE could not be used to predict the downhole geology of Hole 504B.

The velocity-depth function obtained by well logging in the upper $200 \mathrm{~m}$ is not consistent with the OSE observations. The deeper velocities, however, are consistent between the OSE and logging results. In addition, the sonic logging results agree with in situ electrical resistivity and bulk porosity measurements made in Hole 504B (Becker et al., 1982, Newmark et al., Salisbury et al., Becker, all this volume). Thus, we conclude that the velocity structure in the upper $200 \mathrm{~m}$ is highly variable within the survey area. Borehole logging and geologic results 


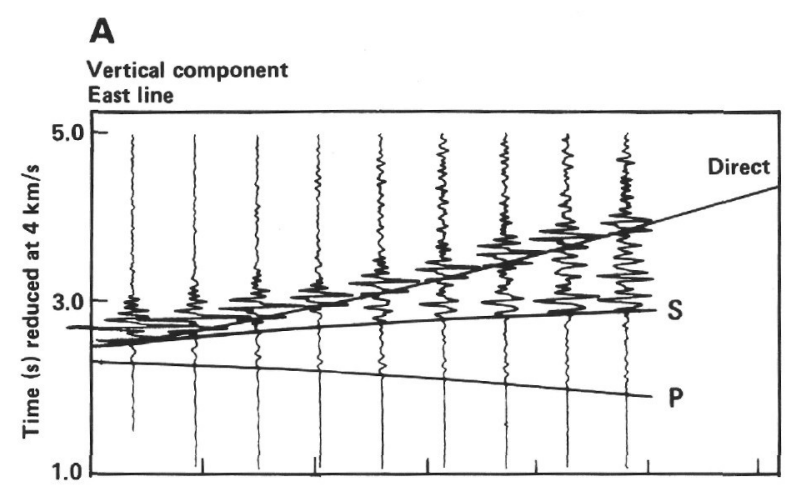

B

Vertical component

West line
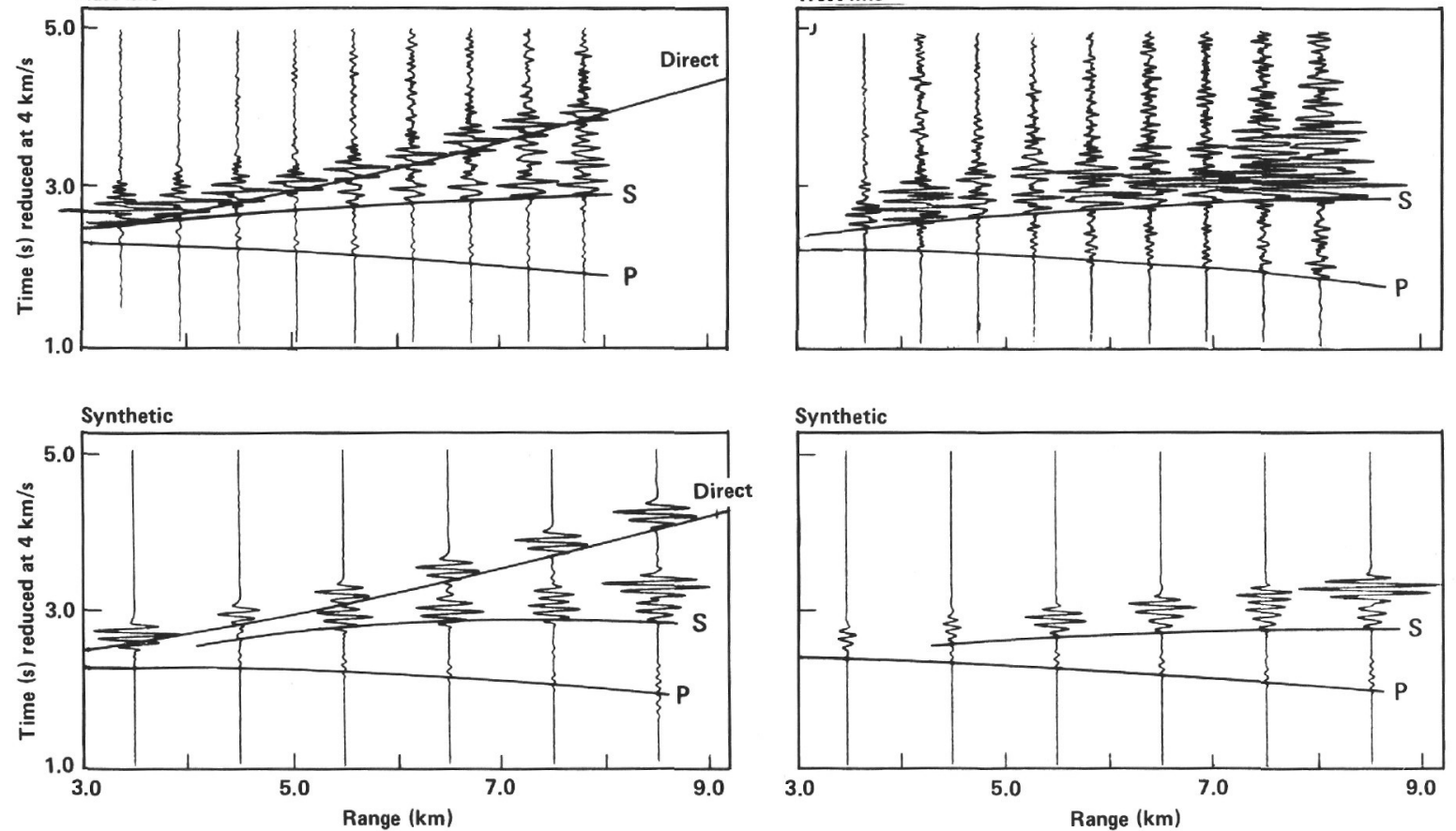

Synthetic

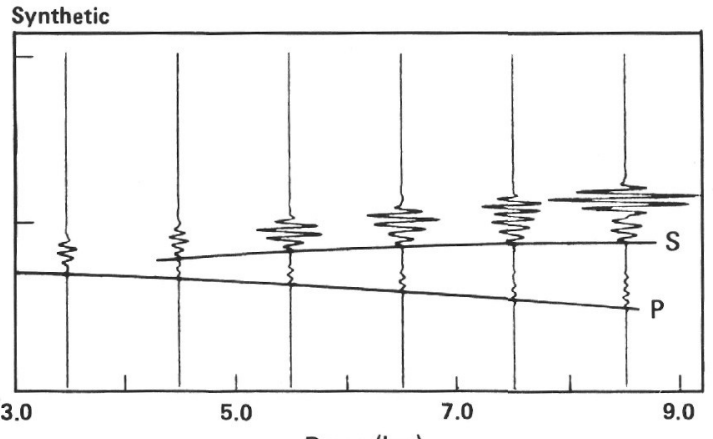

C

Vertical component

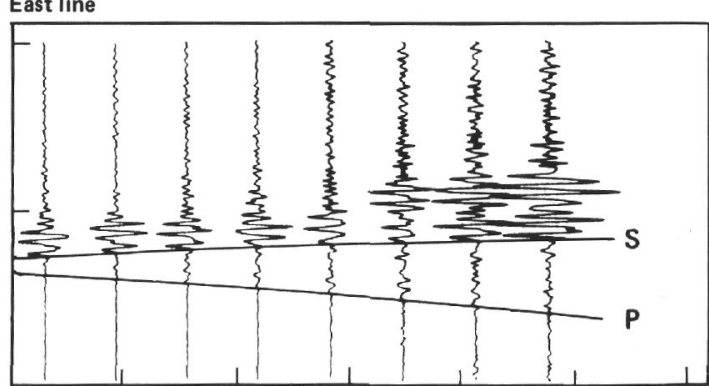

Synthetic

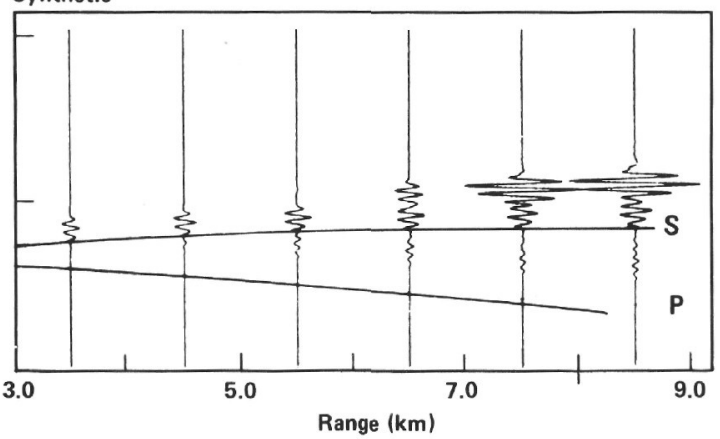

Figure 11. The reflectivity method was used to forward-model the mean velocity-depth function to obtain synthetic seismograms with amplitude information, to be compared with the real amplitude data. A. Receiver $32 \mathrm{~m}$ into basement. B. Receiver $272 \mathrm{~m}$ into basement, P and S wave only. C. Receiver $667 \mathrm{~m}$ into basement, P and S wave only. 


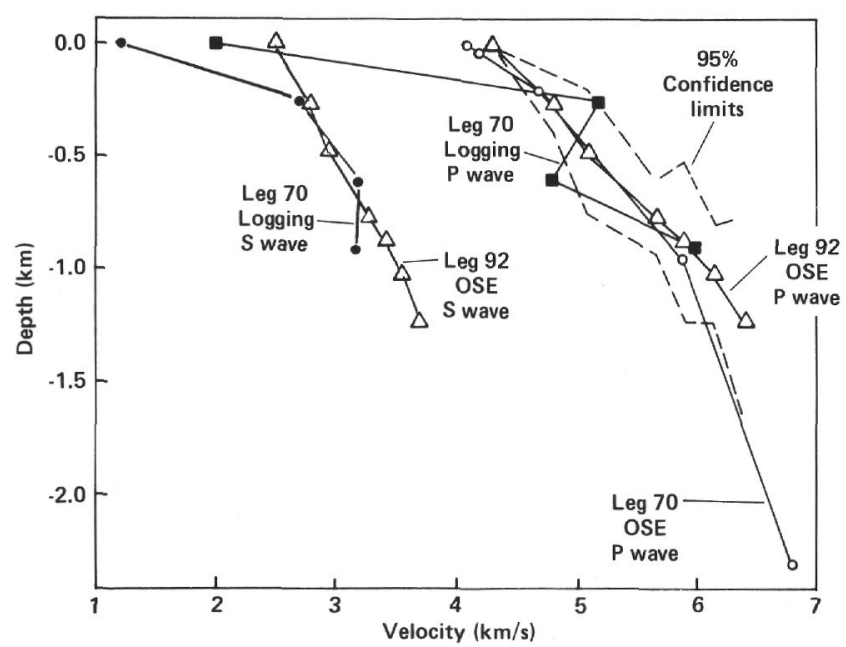

Figure 12. This figure compares the $\mathrm{P}$-wave velocity-depth function obtained on this experiment and the S-wave velocity-depth function by assuming a constant Poisson's ratio of 0.25 to the velocitydepth function obtained during the last OSE on DSDP Leg 70 in Hole 504B, and the P- and S-wave velocity-depth functions obtained by downhole logging on Leg 70 . Note that the logging experiment obtained lower, shallower velocities than did the OSE/s.

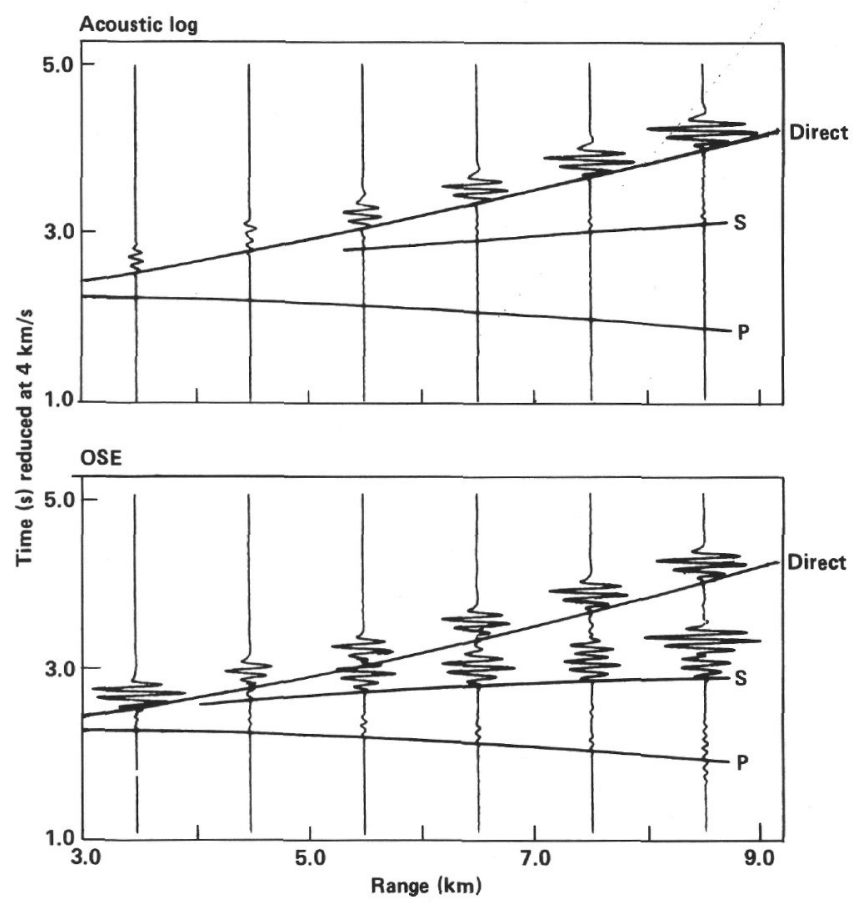

Figure 13. The synthetic seismograms of the logging velocity-depth function are compared to the synthetic seismograms of the Leg 92 OSE for a receiver at $42 \mathrm{~m}$ into basement. Note that the amplitudes of the $\mathbf{S}$ and $\mathbf{P}$ waves are quite different. This indicates that the logging results cannot be generalized to crust in the surrounding few kilometers.

should not be extrapolated to lateral ranges of more than several hundred meters.

Anisotropy was detected from the traveltimes of the 2-km-radius circle shot to the receiver $42 \mathrm{~m}$ into basement. The higher velocity of $4.8 \mathrm{~km} / \mathrm{s}$ east-west parallels the Costa Rica Rift axis, whereas the lower velocity of $4 \mathrm{~km} / \mathrm{s}$ north-south is perpendicular to it. This anisotropy could be due to cracks oriented east-west, parallel to the spreading axis and formed when the crust around Site 504 was created at the ridge, 5.9 m.y. ago.

\section{ACKNOWLEDGMENTS}

We would like to extend our appreciation to the DSDP personnel aboard Glomar Challenger on DSDP Leg 92. Mike Storms, Pat Thompson, and the Scripps electrical technicians worked long hours under trying circumstances to help make our experiment a success. Ted Gustafson and the Scripps marine technicians assisted in the shooting program and maintained a bridge watch on the Challenger. They were a tremendous boon to the experiment. Captain Beattie, the crew of the Ellen B. Scripps, and the WHOI participants carried out extremely competent shooting-ship operations. Of course, Captain Clarke and the Global Marine personnel were extremely cooperative on the Glomar Challenger. We regret that because of the retirement of the Glomar Challenger, we will no longer be able to work with them.

We would also like to thank Tom Bolmer and M. D. Allison for their assistance in data reduction. The work was supported by the U.S. National Science Foundation (Contract No. OCE81-17571) and S. A. Little was supported by the Center for Analysis of Marine Systems. WHOI Contribution No. 5779.

\section{REFERENCES}

Anderson, R. N., Honnorez, J., Becker, K., Adamson, A. C., Alt, J. C., Emmermann, R., Kempton, P. D., Kinoshita, H., Laverne, C., Mottl., M. J., and Newmark, R. L., 1982. DSDP Hole 504B, the first reference section over $1 \mathrm{~km}$ through Layer 2 of the oceanic crust. Nature, 300:589-594.

Anderson, R. N., and Zoback, M. D., 1982. Permeability, underpressures, and convection in the oceanic crust near the Costa Rica Rift, eastern equatorial Pacific. J. Geophys. Res., 87:2860-2868.

Ballard, R. D., Bryan, W. B., Heirtzler, J. R., Keller, G., Moore, J. G., and van Andel, T. H., 1975. Manned submersible operations in the FAMOUS area: Mid-Atlantic Ridge. Science, 190:103-108.

Ballard, R. D., and van Andel, T. H., 1977. Morphology and tectonics of the inner rift valley at lat $36^{\circ} 50^{\prime} \mathrm{N}$ on the Mid-Atlantic Ridge. Geol. Soc. Am. Bull., 88:507-530.

Becker, K., Langseth, M. G., and Von Herzen, R. P., 1983. Deep crustal geothermal measurements, Hole 504B, Deep Sea Drilling Project Legs 69 and 70. In Cann, J. R., Langseth, M. G., Honnorez, J., Von Herzen, R. P., White, S. M., et al., Init. Repts. DSDP, 69: Washington (U.S. Govt. Printing Office), 223-236.

Becker, K., Von Herzen, R. P., Francis, T. J. G., Anderson, R. N., Honnorez, J., Adamson, A. C., Alt, J. C., Emmermann, R., Kempton, P. D., Kinoshita, H., Laverne, C., Mottl, M. J., and Newmark, R. L., 1982. In situ electrical resistivity and bulk porosity of the oceanic crust, Costa Rica Rift. Nature 300:594-598.

CRRUST (Shipboard parties of DSDP Legs 68, 69, and 70), 1982. Geothermal regimes of the Cost Rica Rift, East Pacific, investigated by drilling, DSDP-IPOD Legs 68, 69, and 70. Geol. Soc. Am. Bull., 93:862-875.

Dorman, L. M., and Jacobson, R. S., 1981. Linear inversion of body wave travel time data. Geophysics, 46:138-151.

Fuchs, K., and Müller, G., 1971. Computation of synthetic seismograms with the reflectivity method and comparison with observations. Geophys. J. R. Astr. Soc., 23:417-433.

Houtz, R., and Ewing, J., 1976. Upper crustal structure as a function of plate age. J. Geophys. Res., 81:2490-2498.

Langseth, M. G., Cann, J. R., Natland, J. H., and Hobart, M., 1983. Geothermal phenomena at the Costa Rica Rift: Background and objectives for drilling at Deep Sea Drilling Project Sites 501, 504, and 505. In Cann, J. R., Langseth, M. G., Honnorez, J., Von Herzen, R. P., White, S. M., et al., Init. Repts. DSDP, 69: Washington (U.S. Govt. Printing Office), 5-29.

Lister, C. R. B., 1977. Estimators for heat flow and deep rock properties based on boundary layer theory. Tectonophysics, 41:157-172.

Luyendyk, B. P., and Macdonald, K. C., 1977. Physiography and structure of the inner floor of the FAMOUS rift valley: observations with a deep-towed instrument package. Geol. Soc. Am. Bull., $88: 648-663$ 


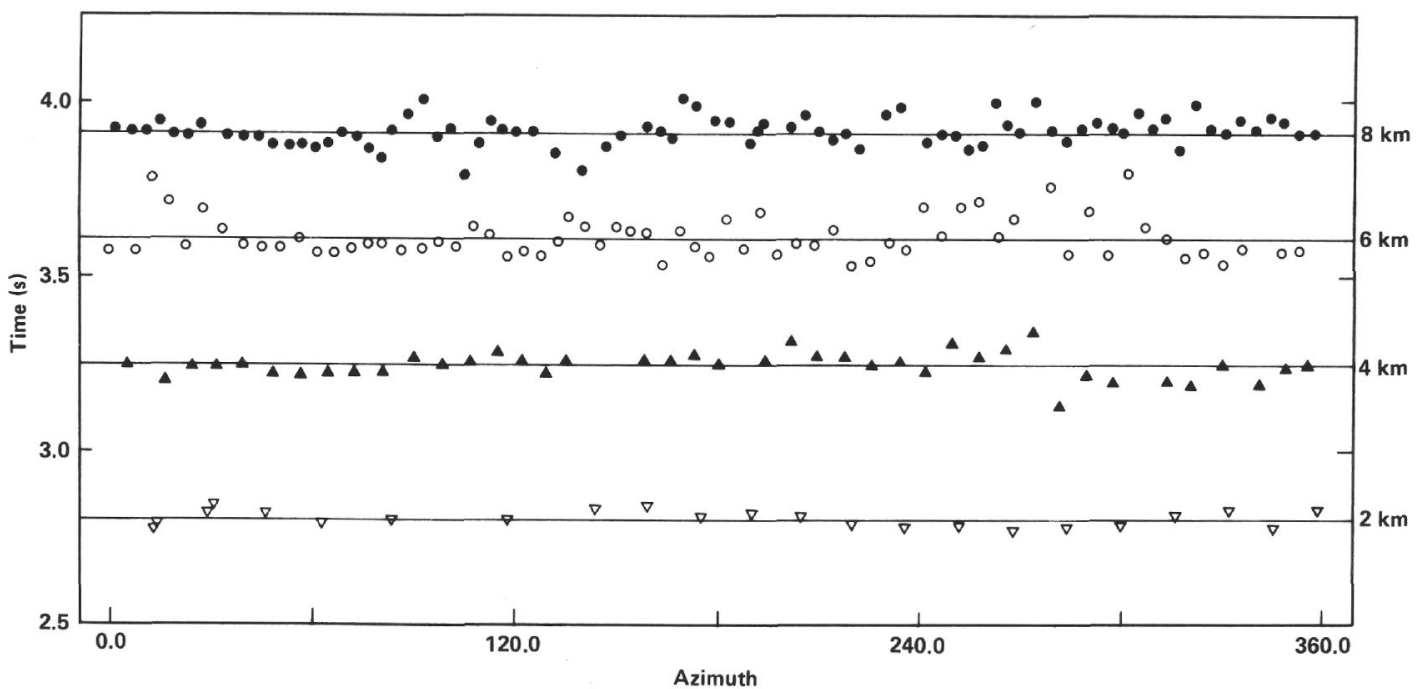

Figure 14. Traveltime (P-wave arrivals) as a function of azimuth for the 2, 4, 6, and $8 \mathrm{~km}$ circles shot to the receiver at $42 \mathrm{~m}$ into basement. The scatter in the longer-range circles makes it impossible to discern anisotropy from traveltimes alone. However, in the $2 \mathrm{~km}$ circle there is a significant azimuthal variation corresponding to a higher velocity $(4.8 \mathrm{~km} / \mathrm{s}) \mathrm{E}-\mathrm{W}$ and a lower velocity $(4.0 \mathrm{~km} / \mathrm{s}) \mathrm{N}-\mathrm{S}$.

Macdonald, K. C., and Luyendyk, B. P., 1977. Deep-tow studies of the structure of the Mid-Atlantic Ridge crest near lat. $37^{\circ} \mathrm{N}$. Geol. Soc. Am. Bull., 88:621-636.

Parsons, B., and Sclater, J. G., 1977. An analysis of the variation of ocean floor bathymetry and heat flow with age. J. Geophys. Res., 82:803-827.

Shure, L., and Chave, A. D., in press. Comment on "An inverse approach to signal correlation" by D. Martinson, W. Menke, and P. Stoffa. J. Geo. Res.

Stephen, R. A., 1977. Synthetic seismograms for the case of the receiver within the reflectivity zone. Geophys. J. R. Astr. Soc., 51: 169-181.

1978. The oblique seismic experiment in oceanic crust [Ph. D dissert.]. Dept. of Geodesy and Geophysics, Cambridge, U.K. , 1979. The oblique seismic experiment in oceanic crust: Equipment and technique. Mar. Geophys. Res., 4:213-226.

, 1981. Seismic anisotropy observed in upper oceanic crust. Geophys. Res. Lett., 8:865-868.

, 1983. The oblique seismic experiment on Deep Sea Drilling Project Leg 70. In Cann, J. R., Langseth, M. G., Honnorez, J., Von Herzen, R. P., White, S. M., et al., Init. Repts. DSDP, 69: Washington (U.S. Govt. Printing Office), 301-308.

Stephen, R. A., and Bolmer, S. T., in press. The direct wave root in marine seismology. Bull. Seism. Soc. Am.

Stephen, R. A., and Harding, A. J., 1983. Travel time analysis of borehole seismic data. J. Geophys. Res., 88:8289-8298.

Stephen, R. A., Johnson, S., and Lewis, B., 1983. The oblique seismic experiment on Deep Sea Drilling Project Leg 65. In Lewis, B. T. R., Robinson, P., et al., Init. Repts. DSDP, 65: Washington (U.S. Govt. Printing Office), 319-327.

Stephen, R. A., Louden, K. E., and Matthews. D. H., 1979. The oblique seismic experiment on Deep Sea Drilling Project Leg 52. In Donnelly, T., Francheteau, J., Bryan, W., Robinson, P., Flower, M., Salisbury, M., et al., Init. Repts. DSDP, 51, 52, 53, Pt. 1: Washington (U.S. Govt. Printing Office), 675-704.

1980. The oblique seismic experiment on DSDP Leg 52. Geophys. J. R. Astron. Soc., 60:289-300.

White, R. S., and Stephen, R. A., 1980. Compressional to shear wave conversion in oceanic crust. Geophys. J. R. Astr. Soc., 63:547-565.

Zoback, M. D., and Anderson, R. N., 1983. Permeability, underpressures, and convection in the oceanic crust at Deep Sea Drilling Project Hole 504B. In Cann, J. R., Langseth, M. G., Honnorez, J., Von Herzen, R. P. White, S. M., et al., Init. Repts. DSDP, 69: Washington (U.S. Govt. Printing Office), 245-254.

Date of Initial Receipt: 4 May 1984

Date of Acceptance: 13 August 1984
Table 3. 2-km-circle Fourier decomposition coefficients (in seconds).

\begin{tabular}{|c|c|c|c|c|c|}
\hline $\cos (x)$ & $\sin (x)$ & $\cos (2 x)$ & $\sin (2 x)$ & $\cos (3 x)$ & $\sin (3 x)$ \\
\hline-0.0045 & 0.01 & 0.0148 & -0. & -0.0066 & 0.0025 \\
\hline $\cos (4 x)$ & $\sin (4 x)$ & $\cos (5 x)$ & $\sin (5 x)$ & $\cos ($ & $\sin (6 x)$ \\
\hline 0,0 & 0.0 & 0.005 & 0.00 & -0.0075 & 0.0005 \\
\hline
\end{tabular}

Equivalently:

$\begin{array}{lll}\begin{array}{c}\text { Amplitude } \\ (\mathrm{s})\end{array} & \begin{array}{c}\text { Phase } \\ \left({ }^{\circ}\right)\end{array} \\ x & 0.013 & 110 \\ 2 x & 0.016 & 340 \\ 3 x & 0.007 & 159 \\ 4 x & 0.009 & 207 \\ 5 x & 0.005 & 194 \\ 6 x & 0.008 & 176\end{array}$

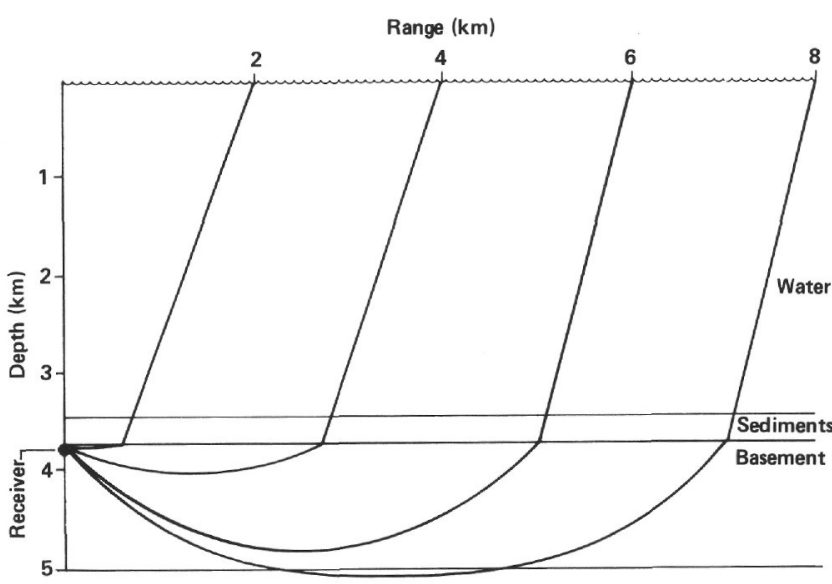

Figure 15. The ray paths for the circles in Figure $14(2,4,6$, and 8 $\mathrm{km})$. Note that the $2 \mathrm{~km}$ ray path samples the area near the drill site, within a $1 \mathrm{~km}$ radius and $100 \mathrm{~m}$ depth. This indicates that the anisotropy is localized and shallow. 